\title{
PENGEMBANGAN MODEL KOMUNIKASI PEMASARAN KOPERASI JASA KEUANGAN SYARIAH DI JAWA BARAT
}

\author{
Studi Kasus Pengembangan Model Komunikasi Pemasaran \\ KBMT Bina Insan Mandiri di Kabupaten Bogor Provinsi Jawa Barat \\ Oleh \\ Ilham Gemiharto \\ Dosen Program Studi Manajemen Komunikasi Universitas Padjadjaran
}

\begin{abstract}
ABSTRAK
Tulisan ini membahas hasil penelitian mengenai pengembangan model komunikasi pemasaran bagi koperasi sebagai upaya penguatan kelembagaan ekonomi masyarakat dengan mengambil studi kasus pengembangan model komunikasi pemasaran salah satu koperasi jasa keuangan syariah di Kabupaten Bogor Provinsi Jawa Barat. Sektor pemasaran bagi lembaga koperasi yang memiliki usaha dalam bidang keuangan merupakan sektor yang vital untuk dapat terus berkembang.

Penelitian ini menggunakan metode penelitian kualitatif dengan teknik pengumpulan data menggunakan observasi, wawancara, dan dokumentasi dan teknik analisis data deskriptif. Penelitian ini mengevaluasi model komunikasi pemasaran yang selama ini dijalankan oleh koperasi sebagai suatu lembaga ekonomi masyarakat. Dengan mengambil studi kasus dari koperasi jasa keuangan syariah di Kabupaten Bogor, melalui penelitian ini dikembangkan suatu model komunikasi pemasaran yang lebih memadai bagi koperasi yang bergerak dalam bidang keuangan dan pembiayaan berbasis syariah yang diharapkan dapat meningkatkan perekonomian masyarakat.

Dari hasil penelitian ditemukan beberapa faktor yang menyebabkan tertinggalnya badan usaha koperasi dibandingkan badan usaha lainnya jika dilihat dari aspek komunikasi pemasarannya. Diantaranya adalah biaya operasional yang relatif tinggi sedangkan bagi hasil rendah, jenis layanan masih terbatas, produk kurang dikenal pasar, rendahnya kompetensi pengurus koperasi, belum menerapkan teknik pemasaran yang efektif, dan wilayah pemasarannya masih bersifat lokal.
\end{abstract}

Kata kunci: model komunikasi pemasaran, koperasi jasa keuangan syariah, Kabupaten Bogor.

\section{Pendahuluan}

Berdasarkan data Badan Pusat Statistik (BPS) pada bulan Maret 2016, jumlah penduduk Indonesia yang masuk dalam kategori miskin tercatat sebanyak 28,01 juta jiwa (10,86 persen). Kriteria miskin tersebut berdasarkan konsumsi masyarakat di bawah Rp 123.000 per bulan. Dengan asumsi sebesar itu, maka buruh yang mendapatkan upah sebesar Rp 450.000 per bulan sesuai dengan KHM (Kebutuhan Hidup Minimum), tidak termasuk dalam kategori miskin. meskipun sesungguhnya mereka adalah kelompok kaum dhu'afa. 
Berbeda dengan kriteria BPS, catatan International Labour Organization (ILO), menunjukkan bahwa penduduk yang berpenghasilan di bawah Rp 1 juta per bulan, dikategorikan sebagai masyarakat miskin. Sebab, ILO memasukkan sejumlah komponen seperti kebutuhan pendidikan, kesehatan, rekreasi dan kebutuhan lainnya (KHL, kebutuhan hidup layak). Seandainya BPS menggunakan kriteria miskin berdasarkan standar ILO, tentu jumlah penduduk Indonesia yang masuk kategori miskin akan meningkat dua sampai tiga kali lipat dari angka yang disebutkan BPS, atau sekitar 85 juta jiwa.

Untuk mengurangi kemiskinan yang demikian menggurita, diperlukan sebuah gerakan nyata dan implementatif. Salah satu upaya strategis untuk mengentaskan kemiskinan tersebut adalah melalui Koperasi Jasa Keuangan Syariah (KJKS) yang lebih dikenal dengan Koperasi Baitul Mal wat Tamwil (KKBMT). Lembaga keuangan ini telah terbukti dapat memberdayakan masyarakat kelas paling bawah (grass root) secara signifikan. Dalam kurun waktu dua dasawarsa (1995 - 2015), di Indonesia telah tumbuh dan berkembang lebih dari 6.000 KBMT, dengan aset lebih dari Rp 3 triliun, melayani lebih dari 3 juta penabung dan memberikan pinjaman terhadap 2,5 juta pengusaha mikro dan kecil. KBMT sebanyak itu telah mempekerjakan tenaga pengelola sebanyak 31.000 orang. (Pinbuk, 2015).

Beberapa KKBMT yang telah berkembang pesat, diantaranya adalah KKBMT Dinar di Karang Anyar memiliki aset Rp 31 milyar. Demikian juga KKBMT Bina Usaha Sejahtera di Lasem Jawa Tengah Rp 28 milyar, KKBMT MMU di Pasuruan Jatim, Rp 17 milyar, KKBMT Marhamah, di Wonosobo, Rp 13 milyar, KKBMT Tumang di Boyolali, Rp 4 milyar, KKBMT Baitur Rahman di Bontang, Kaltim, Rp 6 milyar, dan KKBMT PSU Malang, Rp 5,6 milyar.

Konsep KKBMT di Indonesia sudah bergulir selama dua dekade. Konsep ini telah banyak mengalami pembuktian-pembuktian dalam mengurangi kemiskinan. Peran lembaga ini dalam mengurangi angka kemiskinan sangat strategis, mengingat lembaga pembiayaan belum mampu menyentuh masyarakat akar rumput (fakir, miskin dan kaum dhu'afa lainnya). Akses mereka terhadap pembiayaan sangat kecil, bahkan hampir tak ada sama sekali. Mereka juga tidak punya agunan dan tidak pandai membuat proposal.

Peran strategis KBMT dalam mengurangi kemiskinan terlihat dari kegiatan ekonomi KBMT yang mempunyai kegiatan sosial (Baitul Mal) dan kegiatan bisnis (at-Tamwil). Kegiatan sosial ekonomi KBMT dilakukan dengan gerakan zakat, infaq sedeqah dan waqaf. Hal ini merupakan keunggulan KBMT dalam mengurangi kemiskinan. Dengan menggunakan 
dana Zakat Infaq Shodaqoh dan Wakaf (ZISWAF) ini, KKBMT menjalankan produk pinjaman kebajikan (qardhul hasan).

Kegiatan sosial KBMT ini dapat disebut sebagai upaya proteksi atau jaminan sosial yang dapat menjaga proses pembangunan masyarakat miskin secara signifikan, sebagaimana dinyatakan Amartya Sen (2000). Proteksi sosial ini menjamin distribusi kesejahteraan masyarakat yang tidak punya kepada masyarakat yang punya. Di sinilah KBMT berperan sebagai agent of aset distribution yang mampu memberdayakan ekonomi ummat. Fungsi sosial KBMT ini, sekaligus akan dapat menciptakan hubungan harmonis antara dua kelas yang berbeda.

Dengan adanya pola pinjaman sosial (qardhul hasan) semacam ini, maka KBMT tidak memiliki resiko kerugian dari kredit macet yang dialokasikan untuk masyarakat paling miskin, karena produk qardhul hasan, bersifat non profit oriented, Jika KBMT sebagai Baitul Mal berfungsi sebagai lembaga sosial, maka KBMT sebagai Baitul Tamwil berfungsi sebagai lembaga bisnis yang profit oriented. Dalam menjalankan fungsi ini, KBMT memberikan pembiayaan dengan konsep syariah, antara lain mudharabah dan musyarakah (bagi hasil), jual beli (murabahah, salam, istisna') dan ijarah (sewa), dan rahn (gadai). Konsep bagi hasil untuk sebagian besar rakyat Indonesia merupakan konsep lama dan sudah menjadi bagian dari proses pertukaran aktivitas ekonomi masyarakat.

Kegiatan bisnis yang dijalankan KBMT jauh lebih unggul dari BPR (Pembiayaan Perkreditan Rakyat), karena KBMT tidak saja bergerak dalam usaha simpan pinjam di sektor finansial, tetapi juga dapat menjalankan usaha sektor riil secara langsung. Dua keutamaan inilah yang membuat KBMT menjadi sebuah institusi yang paling cocok dalam mengatasi permasalahan kemiskinan yang dialami sebagian besar rakyat Indonesia (terutama di daerah perdesaan) dewasa ini. Dua sisi pengelolaan dana (Baitul Maal dan Baitul Tamwil) ini seharusnya berjalan seiring, jika salah satu tidak ada maka konsep tersebut menjadi pincang dan menjadi tidak optimal dalam pencapaian tujuan-tujuanya.

Dalam upaya mengembangkan model komunikasi pemasaran yang efektif perlu melibatkan masyarakat, koperasi dan pemerintah. Kesadaran masyarakat mengenai pentingnya pengembangan ekonomi melalui koperasi berbasis syariah perlu terus ditingkatkan. Dengan adanya model komunikasi pemasaran yang tepat diharapkan dapat memajukan koperasi dan meningkatkan perekonomian masyarakat. 


\section{Metode dan Teknik Penelitian}

Penelitian mengenai model komunikasi pemasaran koperasi jasa keuangan syariah di Kabupaten Bogor ini menggunakan metodologi kualitatif. Metode analisis penelitian ini yang digunakan adalah analisis studi kasus berdasarkan metode, data, dan triangulasi sumber. Sedangkan metode pengumpulan data dalam penelitian ini adalah melalui penelitian dokumen dan penelitian lapangan berupa obsevasi dan wawancara. Data yang dikumpulkan dalam penelitian ini terbagi menjadi data primer dan data sekunder. Data primer merupakan hasil observasi dan wawancara dengan 15 informan penelitian di lokasi penelitian, sementara data sekunder adalah data yang diperoleh dari situs-situs berita online (website), jurnal-jurnal komunikasi, serta buku-buku yang relevan dengan penelitian ini.

Berdasarkan asumsi-asumsi di atas, penelitian ini secara praktis berusaha untuk mengkaji peristiwa kehidupan yang nyata yang dialami oleh subjek penelitian ini secara holistik dan bermakna. Dalam uraian yang lebih lugas, penelitian ini berusaha untuk memberikan deskripsi dan eksplanasi terhadap model komunikasi pemasaran koperasi jasa keuangan syariah di Kabupaten Bogor.

Teknik analisis data yang digunakan dalam penelitian ini adalah mengacu pada konsep Miles \& Huberman (2012: 20) yaitu interactive model yang mengklasifikasikan analisis data dalam tiga langkah, yaitu Reduksi data (Data Reduction), Penyajian data (Display Data), dan Pengujian Keabsahan Data (Verifikasi). Untuk menguji keabsahan data yang didapat sehingga benar-benar sesuai dengan tujuan dan maksud penelitian, maka peneliti menggunakan teknik triangulasi. Triangulasi data adalah teknik pemeriksaan data yang memanfaatkan sesuatu yang lain diluar data tersebut untuk keperluan pengecekan atau sebagai pembanding data tersebut (Moleong, 2007: 330).

\section{Hasil dan Pembahasan}

\section{Gambaran Umum Penelitian}

Lokasi penelitian ini mengambil lokasi di salah satu Koperasi Jasa Keuangan Syariah (KJKS), yaitu Koperasi Baitul Mal wal Tamwil (KBMT) Bina Insan Mandiri, yang berlokasi di Kecamatan Citeureup, Kabupaten Bogor, Provinsi Jawa Barat. Di koperasi yang menjadi lokasi penelitian, peneliti mewawancarai anggota koperasi jasa keuangan syariah yang dipilih secara acak (random). Selain para anggota koperasi, peneliti juga mewawancarai para pengurus Koperasi. Sehingga dalam penelitian ini terdapat 10 informan penelitian, yang terdiri dari 6 (enam) anggota koperasi, dan 4 (empat) orang pengurus koperasi. 
Untuk melaksanakan tahapan Triangulasi tim peneliti mewawancarai Kepala Dinas Koperasi dan UKM Kabupaten Bogor selaku pimpinan Organisasi Perangkat Daerah (OPD) pelaksana bidang Koperasi di Kabupaten Bogor dan juga Camat Citeureup sebagai Kepala Daerah di lokasi penelitian di Kabupaten Bogor.

Profil Koperasi Baitul Mal wal Tamwil (KBMT) Bina Insan Mandiri

Koperasi Baitul Mal wal Tamwil (KBMT) Bina Insan Mandiri adalah salah satu Koperasi Jasa Keuangan Syariah (KJKS) yang telah secara resmi berbadan hukum sejak tahun 2007, dengan nomor Badan Hukum 518/86/BH/KPTS/Kankop/07 yang diterbitkan tanggal 8 Januari 2007. KBMT Bina Insan Mandiri beralamat di Jl. Pahlawan No. 258 Desa Sanja, Kecamatan Citeureup Kabupaten Bogor.

Secara kelembagaan Koperasi Baitul Mal wal Tamwil (KBMT) Bina Insan Mandiri sebagai salah satu koperasi jasa keuangan syariah di Kabupaten Bogor telah melengkapi seluruh persyaratan pendirian koperasi dan sudah menjalankan organisasinya menurut aturan yang berlaku. Koperasi ini juga telah memiliki struktur organisasi dan personil yang siap melaksanakan tugas menjalankan roda organisasi, selain itu Koperasi telah memiliki Standar Operasional Prosedur (SOP) yang akan membuat sistem dalam koperasi akan bekerja dengan baik jika SOP tersebut dilaksanakan oleh masing-masing pemegang tanggung jawab dan wewenangnya.

Profil anggota koperasi sudah tersedia, sehingga pengurus pada tahap ini telah memiliki data base anggota yang dapat dijadikan acuan membuat program kerja yang sesuai dengan kebutuhan anggota. Secara umum dari sisi kelembagaan koperasi telah memiliki Badan Hukum, SIUP, NPWP dan TDP, Struktur organisasi, Anggaran Dasar (AD), Anggaran Rumah Tangga (ART), Standar Operasional Prosedur (SOP) Organisasi, Standar Operasional Prosedur (SOP) Usaha, dan Program Kerja Tahunan.

Dengan terpenuhinya kelengkapan administrasi KBMT Bina Insan Mandiri, maka secara organisasi KBMT Bina Insan Mandiri dapat menjalankan organisasi dan usahanya sesuai aturan hukum yang berlaku. Adapun wilayah kerja KBMT Bina Insan Mandiri meliputi 5 (lima) kecamatan di Kabupaten Bogor, yaitu Kecamatan Citeureup, Cibinong, Babakan Madang, Klapanunggal, dan Gunungputri.

KBMT Bina Insan Mandiri sesuai dengan tujuan awal didirikan untuk meningkatkan kesejahteraan masyarakat. Saat ini KBMT Bina Insan Mandiri telah memiliki 300 orang anggota, dimana semua anggota sudah menyetorkan simpanan pokok dan simpanan wajib, 
sebagai syarat untuk dapat memanfaatkan produk jasa keuangan syariah dari KBMT Bina Insan Mandiri.

Kendala yang dihadapi koperasi saat ini adalah keterbatasan jumlah modal sehingga menyebabkan koperasi kesulitan untuk mengembangkan usahanya karena koperasi belum bisa memenuhi semua permintaan pinjaman anggota. Kemampuan koperasi untuk memberikan pinjaman kepada anggota juga masih terbatas dalam nominal di bawah lima puluh juta rupiah. Hal ini menjadi salah satu kendala karena anggota umumnya menginginkan pinjaman yang lebih besar, tidak hanya untuk modal awal usaha, tetapi juga untuk modal pengembangan usaha yang membutuhkan dana yang lebih besar. Oleh karena itu Koperasi perlu mencari alternatif sumber permodalan dari luar anggota, misalnya melalui penyertaaan modal dari pihak eksternal atau investasi pada lembaga keuangan syariah lainnya. Sumber permodalan sangat penting bagi koperasi, khususnya dalam memberikan pelayanan berupa pemberian pinjaman kepada anggota koperasi. Tanpa adanya pelayanan yang memadai kepada anggota, kemungkinan koperasi akan sulit untuk mendapatkan anggota-anggota baru.

KBMT Bina Insan Mandiri saat ini telah mengadopsi sistem administrasi keuangan yang cukup baik dan telah memiliki satu orang staf administrasi keuangan yang bertugas untuk melaksanakan pencatatan transaksi keuangan dan menyelenggarakan pembukuan Koperasi. Staf administrasi keuangan ini telah mendapat pelatihan mengenai sistem keuangan koperasi baik dari Dinas KUKM Kabupaten Bogor sehingga diharapkan mampu untuk melaksanakan tugas-tugasnya dengan baik. Dengan adanya staf keuangan ini, ketua koperasi dapat lebih fokus menjalankan tugasnya.

KBMT Bina Insan Mandiri juga telah memiliki Manual Pembukuan yang menjadi acuan terhadap pelaksanaan pencatatan setiap transaksi. Manual Pembukuan menjelaskan secara rinci prosedur pencatatan transaksi dari mulai dokumen transaksi sampai kepada Penyusunan Laporan Keuangan. Dengan adanya Manual Pembukuan ini, diharapkan staf administrasi keuangan dapat melaksanakan tugasnya dengan lebih baik.

Ditinjau dari aspek manajemen, KBMT Bina Insan Mandiri telah mendapatkan akreditasi baik dari Dinas KUKM Kabupaten Bogor, dimana koperasi telah memiliki lebih dari 5 (lima) orang karyawan yang memiliki jenjang karir yang jelas dan seluruh karyawan secara rutin dan berkala mengikuti pelatihan di Dinas KUKM Kabupaten Bogor. Sistem pembukuan sudah menggunakan sistem akuntansi yang terintegrasi.

Kinerja keuangan KBMT Bina Insan Mandiri dalam setahun terakhir cukup baik, dimana koperasi memiliki total aset sebesar 3 miliar rupiah dan Non Performing Loan (Kredit Macet) di 
bawah 10 persen. Sisa Hasil Usaha pada tahun 2015 adalah sebesar 28 juta rupiah. Sedangkan dari aspek infrastruktur yang dimiliki, KBMT Bina Insan Mandiri sudah memiliki kantor beserta seluruh perabotan dan perlengkapan kerja milik sendiri, berikut 3 (tiga) unit komputer yang terhubung dengan internet.

\section{Layanan Jasa Keuangan Syariah KBMT Bina Insan Mandiri}

Layasan Jasa Keuangan KBMT Bina Insan Mandiri didesain untuk bermitra dengan usaha-usaha mikro dan kecil yang tidak tersentuh perbankan, baik konvensional maupun syariah. Selama ini perbankan masih kesulitan untuk mengalirkan dananya ke usaha mikro, hal ini karena jenis usaha ini dinilai kurang ekonomis untuk mendapatkan pembiayaan dari bank. Belum lagi karena berbagai kendala seperti masalah agunan, serta kondisi administrasi keuangan yang dinilai kurang memenuhi syarat. Kegiatan utama BMT adalah menghimpun dana dan mendistribusikan kembali kepada anggota dengan imbalan bagi hasil sesuai syariah.

Dasar-dasar pengelolaan BMT dengan sistim syari'ah tidak menggunakan bunga sebab bunga adalah riba. Komitmen ini berdasarkan pada pengertian mengenai Q.S. 2 :278279, 2 : 275-276, 3:130, 4:29, dan 30:39. Apalagi setelah MUI, dalam Rakernas di Jakarta pada bulan Desember 2004, menyatakan dalam fatwanya bahwa bunga bank haram hukumnya sebab bunga bank adalah riba. Seiring dengan gagasan Islamisasi perbankan, maka BMT pun mempedomani prinsip bagi hasil sebagai pengganti sistim bunga.

Selama ini demi menjaga konsistensi lembaga keuangan yang mengatasnamakan Islam di Indonesia terutama pada level BMT, saat ini lingkup lembaga keuangan Islam sangat mendesak untuk mengembangkan pertukaran pandangan mengenai kemampuan produkproduk keuangan mereka sebagai satu kesatuan dalam kerangka pengganti sistim bunga, yang seharusnya lebih mampu membentuk keadilan ekonomi. Upaya itu adalah kebutuhan dalam kerangka menghilangkan kelemahan lembaga keuangan Islam karena tidak nyangkutnya teori dengan praktik atau antara ilmu dengan kenyataan.

Dalam pembiayaan, fungsi dan layanan BMT tidak berbeda dengan bank syari'ah. BMT juga menjadi penyandang dana bagi pengusaha yang datang kepadanya untuk mengajukan permohonan dana. Besar kecil dana dalam permohonan pengusaha itu pada akhirnya mendapatkan ketetapannya dari pihak BMT.

Jenis-jenis layanan melalui produk BMT pun tidak berbeda dari jenis layanan bank syari'ah, yang dapat dibagi menjadi 3 (tiga) jenis, yaitu jual beli, sistem bagi hasil dan jasa. Layanan jual beli diantaranya adalah ba'i bitsaman ajil, yaitu penjualan barang kepada 
anggota dengan mengambil keuntungan (margin) yang diketahui dan disepakati bersama, sementara pembayaran dilakukan dengan cara mengangsur. Yang kedua adalah murobahah, yaitu penjualan barang kepada anggota dengan mengambil keuntungan (margin) yang diketahui dan disepakati bersama, pembayaran dilakukan dengan cara jatuh tempo/sekaligus. Selanjutnya adalah ba'i assalam, yaitu penjualan hasil produksi (komoditi) yang terlebih dahulu dipesan anggota dengan kriteria tertentu yang sudah umum. Anggota harus membayar uang muka kemudian barang dikirim belakangan (setelah jadi). Kemudian ada pula jual beli istisna', yaitu penjualan hasil produksi (komoditi) pesanan yang didasarkan kriteria tertentu (yang tidak umum) anggota boleh membayar pesanan ketika masih dalam proses pembuatan/setelah barang itu jadi dengan cara sekaligus/mengangsur, dan yang terakhir adalah ijaroh, yaitu pembelian suatu barang yang dilakukan dengan cara sewa terlebih dahulu setelah masa sewa habis maka anggota membeli barang sewa tersebut.

Sementara itu layanan BMT yang menggunakan sistim bagi hasil diantaranya adalah musyarokah, yaitu kerjasama penyertaan modal dan masing-masing menentukan jumlahnya sesuai kesepakatan bersama yang digunakan untuk mengelola suatu usaha/proyek tertentu. Pada prinsipnya dalam pembiayaan musyarokah tidak ada jaminan, namun untuk menghindari terjadinya penyimpangan, Lembaga Keuangan Syariah dapat meminta jaminan. Kerugian harus dibagi antara para anggota secara proporsional menurut saham masing-masing dalam modal.

Partisipasi para mitra dalam pekerjaan merupakan dasar pelaksanaan musyarokah akan tetapi kesamaan porsi kerja bukanlah merupakan syarat. Seorang mitra boleh melaksanakan kerja lebih banyak dari lainnya dalam hal ini ia boleh menuntut bagian keuntungan tambahan bagi dirinya. Hal ini dapat dijadikan dasar dalam penentuan nisbah dimana anggota BMT sebagai pengelola usaha mendapatkan porsi yang lebih tinggi.

Layanan bagi hasil lainnya adalah mudharabah, yaitu pemberian modal kepada anggota yang mempunyai skill untuk mengelola usaha/proyek yang dimilikinya. Pembagian bagi hasil usaha ditentukan berdasarkan kesepakatan. Modal $100 \%$ dari shohibul maal, tidak terdapat jadwal angsuran, bagi hasil tidak ditetapkan dimuka dan sifatnya tidak tetap, tergantung fluktuasi keuntungan yang diperoleh.

BMT sebagai penyandang dana menanggung semua kerugian akibat dari mudharabah kecuali jika mudharib /anggota melakukan kesalahan yang disengaja atau lalai/menyalahi perjanjian. Dalam akad ini biaya operasional dibebankan kepada mudharib. 
Jasa keuangan syariah terakhir adalah Sistim Jasa, yang terdiri dari qord, yaitu pemberian pinjaman untuk kebutuhan mendesak dan bukan bersifat konsumtif. Pengembalian pinjaman sesuai dengan jumlah yang ditentukan dengan cara angsur atau tunai. Contohnya untuk biaya rumah sakit, biaya pendidikan, biaya tenaga kerja.

Sistem jasa lainnya adalah al-wakalah, yaitu pemberian untuk melaksanakan urusan dengan batas kewenangan dan waktu tertentu. Penerima kuasa mendapat imbalan yang ditentukan dan disepakati bersama. Selanjutnya adalah al-hawalah, yaitu penerimaan pengalihan utang/piutang dari pihak lain untuk kebutuhan mendesak dan bukan bersifat konsumtif. BMT sebagai penerima pengalihan hutang/piutang akan mendapatkan fee dari pengaturan pengalihan (management fee).

BMT juga menyediakan jasa gadai barang yang disebut rahn, yaitu pinjaman dengan cara menggadaikan barang sebagai jaminan utang dengan membayar jatuh tempo. Ongkos dan biaya penyimpanan barang (marhum) ditanggung oleh penggadai (rahin). Barang jaminan adalah milik sendiri (rahin), untuk itu hendaknya rahin bersedia mengisi surat pernyataan kepemilikan.

Sementara produk jasa yang terakhir adalah kafalah, yaitu pemberian garansi kepada anggota yang akan mendapatkan pembiayaan (pelaksanaan suatu usaha/proyek) dari pihak lain. BMT mendapatkan fee dari anggota sesuai dengan kesepakatan bersama.

Sebagai salah satu badan usaha jasa keuangan berbasis syariah, saat ini KBMT Bina Insan Mandiri dalam operasionalnya memiliki dua sektor usaha yaitu sektor nirlaba dan sektor bisnis. Namun dalam pembiayaan usaha tidak mengenal riba, namun menggunakan sistem yang lebih adil dan manusiawi yang disebut mudharabah (bagi hasil). Sementara dalam pembiayaan sektor nirlaba, diberlakukan pinjaman tanpa bunga, diantaranya melalui sistem qardhul hasan, atau pinjaman dana kepada nasabah tanpa imbalan dengan hanya mengembalikan pokok pinjaman secara sekaligus atau cicilan dalam jangka waktu tertentu. Qardhul hasan ditujukan bagi orang yang tidak mampu (fakir miskin) untuk modal usaha yang berkelanjutan.

KBMT Bina Insan Mandiri BMT dalam melakukan usaha menghimpun dana dari masyarakat berupa simpanan mempunyai beberapa jenis usaha mudharabah, yaitu simpanan mudharabah biasa, simpanan mudharabah haji, simpanan mudharabah umrah, simpanan mudharabah qurban, simpanan mudharabah idul fitri, simpanan mudharabah walimahan, simpanan mudharabah aqiqah, simpanan mudharabah perumahan. 
Sedangkan dalam usaha menyalurkan dana kepada masyarakat berupa pembiayaan KBMT Bina Insan Mandiri mempunyai beberapa jenis usaha diantaranya, pembiayaan sewa barang (al-ijaroh), pembiayaan modal kerja (murabahah), pembiayaan bagi hasil (mudharabah), pembiayaan kerjasama (musyarakah), pembiayaan investasi (ba'i bitsaman ajil), dan pembiayaan kebijakan (qardhul hasan)

Sejalan dengan sejarah kemunculan perbankan syariah, disini diperlukan suatu penegasan terhadap kedudukan produk-produk syariah tersebut sebagai pengganti bunga bank. Prinsip bagi hasil didalam BMT menjadi gagasan yang mengemuka dalam upaya mencari pengganti bunga, dan penerapannya dilaksanakan dalam pembiayaan mudharabah dan musyarakah.

\section{Konsep Pemasaran KBMT Bina Insan Mandiri}

Menurut Kotler (2008:90), terdapat konsep pokok yang mendasari pemasaran yaitu konsep kebutuhan, keinginan dan permintaan, produk, nilai dan kepuasan, pertukaran atau transaksi, pasar, pemasaran dan pemasar. Kebutuhan dan keinginan manusia menimbulkan permintaan terhadap produk tertentu yang didukung oleh kemampuan untuk membeli. Produk tersebut dapat berguna untuk memuaskan kebutuhan atau keinginan manusia sehingga timbal jual beli yang merupakan tindakan untuk memperoleh produk yang diinginkan atau dibutuhkan dengan menawarkan sesuatu sebagai imbalan. Jadi jual beli dapat dipandang sebagai suatu proses penciptaan nilai dan manfaat suatu produk. Jika kesepakatan antar pihak telah tercapai maka dikatakan telah terjadi suatu transaksi. (Kotler, 2008:92)

Tujuan utama didirikannya KBMT Bina Insan Mandiri untuk peningkatan kesejahteraan masyarakat. Oleh karena itu didalam menyusun rencana pemasaran produk pembiayaan syariah, KBMT Bina Insan Mandiri menempatkan diversifikasi produk pada urutan pertama dalam memberikan pelayanan kepada masyarakat, khususnya kalangan Usaha Mikro dan Kecil (UMK) yang tidak tersentuh oleh kredit perbankan umum sebagai segmen pasar yang dituju. Setelah menentukan segmen pasar yang dituju, maka tahap selanjutnya KBMT Bina Insan Mandiri memilih pasar sasaran yang akan dipenuhi kebutuhannya, diantaranya adalah anggota koperasi yang memerlukan modal Usaha Mikro dan Kecil (UMK).

Pelaku UMK yang menjadi sasaran adalah yang membutuhkan modal usaha di bawah 50 juta rupiah untuk pengembangan usahanya. Dalam memasarkan produk jasa keuangan syariah kepada pelaku UKM yang juga merupakan anggota KBMT Bina Insan Mandiri, para 
staf pemasaran bersikap proaktif menawarkan produk jasa pembiayaan yang sekiranya dibutuhkan oleh masing-masing anggota, karena ada anggota koperasi yang hanya membutuhkan modal yang tidak terlalu besar dengan nominal di bawah 10 juta rupiah, namun ada juga anggota yang membutuhkan modal usaha di atas 30 juta rupiah.

Sebelum mencairkan pembiayaan, sudah menjadi kewajiban staf bagian pembiayaan untuk melakukan survei lapangan dan wawancara dengan anggota koperasi pelaku UMK calon debitur di kediamannya. Hasil survei tersebut dijadikan pedoman dalam penentuan nilai pembiayaan yang akan diberikan kepada mereka. Jumlah akhir pembiayaan yang diberikan mempertimbangkan faktor kemampuan riil anggota untuk memenuhi kesepakatan dalam pembiayaan. Misalnya ada seorang anggota yang mengajukan pembiayaan sebesar 30 juta rupiah, namun setelah dilakukan survei dan wawancara ternyata pengembangan usaha anggota tersebut hanya membutuhkan dana pembiayaan sebesar 10 juta rupiah saja. Selain melakukan survei dan wawancara staf bagian pembiayaan juga memberikan masukan kepada anggota mengenai strategi pengembangan usaha anggota supaya dapat terus maju dan berkembang meskipun dengan modal minim.

\section{Model Komunikasi Pemasaran KBMT Bina Insan Mandiri}

Proses komunikasi pemasaran tidak hanya menghubungkan produsen dengan konsumen, atau antara pembeli dengan penjual, tetapi juga menghubungkan pembeli dengan lingkungan sosialnya. Artinya proses komunikasi pemasaran bisa dimulai dari produsen/penjual, namun bisa pula dimulai dari konsumen/pembeli. Komunikasi pemasaran yang berasal dari penjual terjadi dalam bentuk promosi dan segala macam baurannya, dimana penjual berusaha mengkomunikasikan produk yang dihasilkan kepada masyarakat luas supaya mengenal dan kemudian memutuskan untuk membeli produk jualannya. Sedangkan komunikasi pemasaran yang berasal dari pembeli terjadi dalam bentuk respon yang merupakan akibat dari penggunaan produk dari penjual atau produsen. (Morrisan, 2010:12)

Menurut teori Integrated Marketing Communication (IMC), atau Komunikasi Pemasaran Terintegrasi, produsen atau penjual harus berusaha memaksimalkan pesan positif dan meminimalkan pesan negative dari suatu brand atau merek, dengan sasaran membangun dan memperkuat brand relationship dengan cara membangun hubungan jangka panjang antara produsen dan konsumen. Brand relationship yang positif akan menghasilkan keuntungan dan terus meningkatkan nilai produk yang dijual oleh produsen. (Percy, 2008:172) 
Koperasi Baitul Mal wal Tamwil (KBMT) Bina Insan Mandiri sebagai sebuah lembaga ekonomi masyarakat belum menerapkan teknik komunikasi pemasaran terintegrasi, dan hanya mengandalkan pemasarannya kepada keunggulan produk dan harga (price), tanpa melalui proses komunikasi pemasaran yang efektif. Sejauh ini koperasi hanya bersikap proaktif kepada calon nasabah yang memang telah mengajukan diri untuk mendapatkan pembiayaan sebelumnya, mengingat jumlah anggota yang mengajukan pembiayaan usaha berjumlah diatas 70\%, atau sekitar 210 dari 300 orang anggota koperasi setiap tahun anggaran.

Dengan adanya demand yang tetap, koperasi dituntut untuk dapat meningkatkan kapasitas pembiayaan sehingga dapat memenuhi permintaan pembiayaan seluruhnya (100\%) sebanyak 210 anggota koperasi pelaku UMK setiap tahunnya. Upaya yang dapat dilakukan adalah dengan cara menambah modal koperasi melalui peningkatan jumlah modal, atau dengan menggunakan dana pihak ketiga, misalnya melalui pinjaman lunak lembaga keuangan syariah yang ada di Kabupaten Bogor. Apabila masalah permodalan sudah teratasi maka langkah selanjutnya adalah melakukan peningkatan jumlah pembiayaan dan menekan jumlah Non Performing Loan (kredit macet).

Model komunikasi pemasaran yang dijalankan oleh KBMT Bina Insan Mandiri masih bersifat one-voice dimana komunikasi pemasaran terhadap pembeli dilakukan melalui proses tatap muka tanpa menggunakan media tertentu. Kedekatan lokasi koperasi dengan lokasi anggota menjadi alasan semua proses komunikasi dilakukan melalui proses tatap muka. Pengurus koperasi sebagai promotor maupun pelaku UMK sebagai konsumen merasa nyaman dengan metode komunikasi seperti itu.

Komunikasi pemasaran terintegrasi berarti teknik komunikasi yang digunakan memiliki bauran antara satu unsur dengan unsur lainnya, misalnya antara produk dan harga (price). Misalnya untuk mendapatkan harga yang layak, tentunya koperasi harus mampu menghasilkan produk jasa keuangan yang menawarkan berbagai kemudahan bagai anggotanya. Bauran lainnya bisa dilakukan antara produk, promosi, dan harga. Apabila produk jasa keuangan yang dihasilkan sudah baik sehingga layak untuk dipasarkan, maka untuk meningkatkan jumlah debitur maka harus dilakukan promosi atau iklan. Promosi bertujuan untuk menyebarluaskan informasi kepada masyarakat luas bahwa koperasi memiliki produk pembiayaan tertentu dengan banyak kemudahan, sehingga untuk memperolehnya anggota koperasi bisa mendapatkannya dengan syarat dan ketentuan yang sudah ditetapkan. 
Dari uraian di atas, maka proses pemasaran KBMT Bina Insan Mandiri yang terjadi dapat digambarkan dalam bagan sebagai berikut:

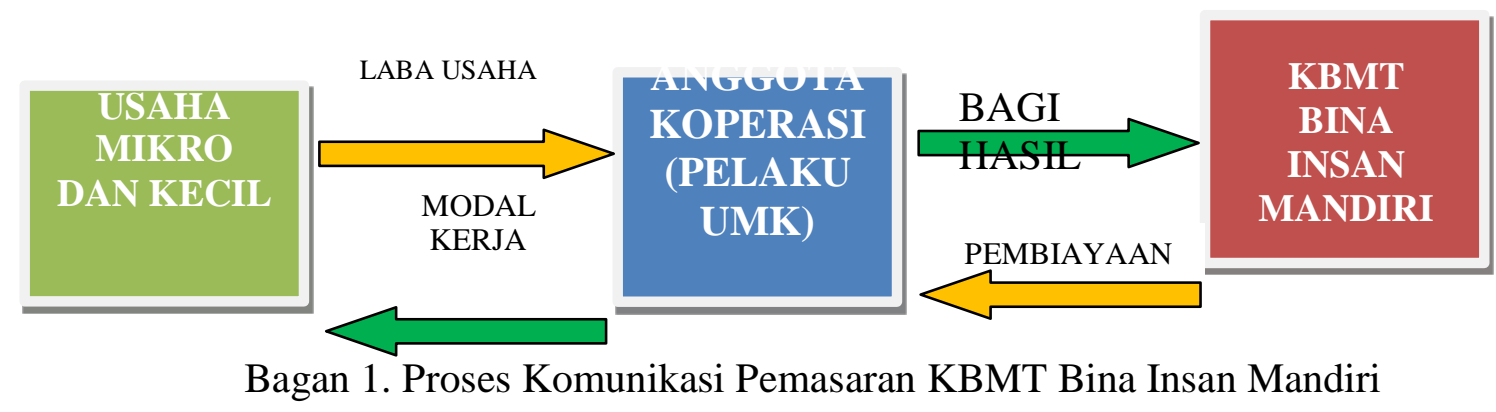

Dengan kapasitas sumber daya manusia yang dimiliki koperasi saat ini, pengurus belum merasa perlu melakukan bauran promosi produk kepada calon debitur. Jadi integrasi pemasaran yang dilakukan adalah hanya pada unsur produk dan harga saja. Namun untuk mengantisipasi perkembangan koperasi selanjutnya, maka perlu dibuat suatu model komunikasi pemasaran yang terintegrasi.

Menurut Sereno dan Mortensen (dalam Mulyana, 2007:48), suatu model komunikasi merupakan deskripsi ideal mengenai apa yang dibutuhkan untuk terjadinya proses komunikasi, artinya proses komunikasi dilakukan dan dipahami sebagai proses penyampaian pesan yang melibatkan umpan balik dari komunikan sebagai pihak yang menerima pesan kepada pesan-pesan atau informasi yang diberikan oleh komunikator, proses tersebut dalam pesan yang terdapat oleh media. Unsur komunikasi yang berkaitan menjadi integral dalam proses penyampaiannya sebagai hubungan yang saling kontinyu, bahwa komunikasi dilakukan seiring dengan keterkaitan unsur komunikasi.

Perencanaan dalam komunikasi pemasaran merupakan panduan mendasar yang penting dalam menyusun sebuah strategi pemasaran berdasarkan model komunikasi pemasaran yang terintegrasi. Untuk dapat menghasilkan perencanaan yang baik mungkin membutuhkan waktu yang lama, namun implementasi dari hasil setiap perencanaan yang tepat akan memberikan keuntungan yang signifikan kepada produsen atau penjual.

Berikut ini adalah model komunikasi pemasaran yang dapat dikembangkan oleh KBMT Bina Insan Mandiri untuk dapat meningkatkan nilai usaha dan keuntungannya: 


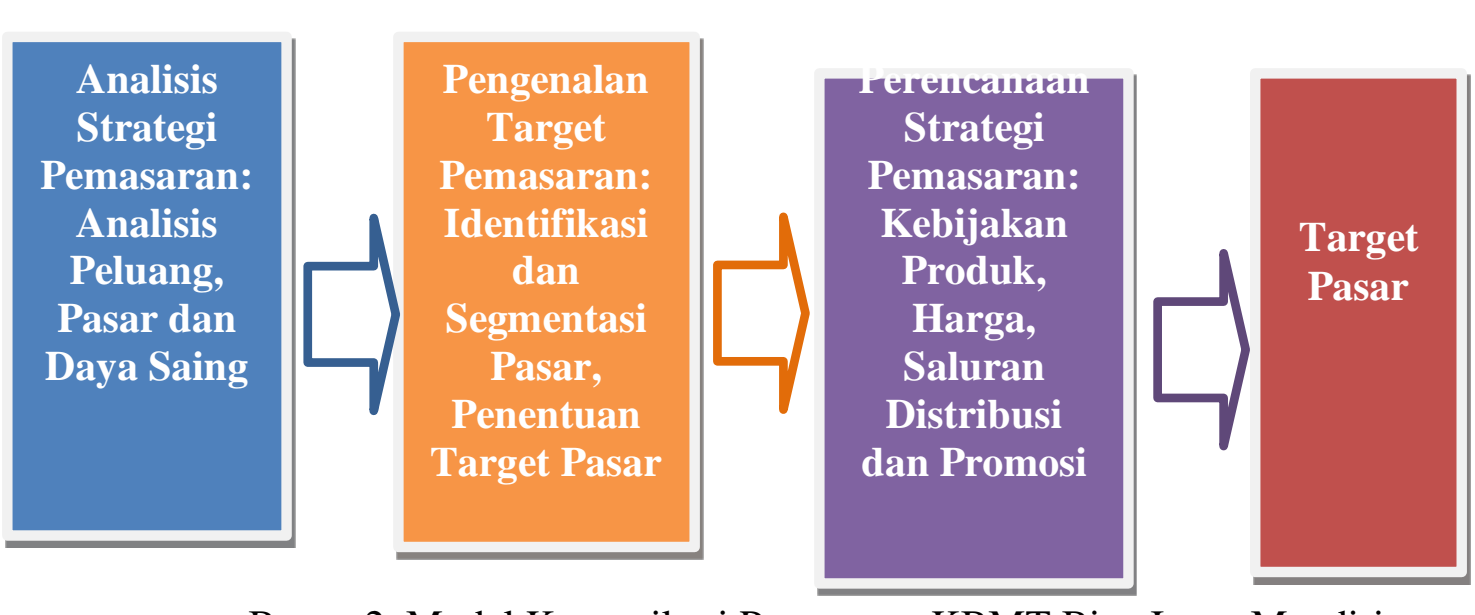

Bagan 2. Model Komunikasi Pemasaran KBMT Bina Insan Mandiri

Dalam model di atas tahapan pemasaran dimulai dengan menganalisis strategi pemasaran berupa analisis peluang, pasar dan daya saing. Analisis peluang berkaitan dengan peluang produk pembiayaan yang dapat diterima oleh pasar, artinya pasar untuk produk tersebut memang masih terbuka lebar. Dengan adanya analisis peluang, maka dipastikan produk yang dihasilkan oleh koperasi memiliki calon pembeli yang pasti. Selanjutnya adalah melakukan analisis pasar, yaitu dengan mempelajari kondisi pasar yang ada untuk produk pembiayaan. Analisis dilakukan dengan melakukan survei produk-produk pembiayaan lain yang ada di pasaran. Dari hasil analisis ini diharapkan didapatkan data mengenai karakter permintaan masing-masing pasar, sehingga koperasi dapat memutuskan lokasi pemasaran produknya. Sedangkan analisis terakhir yang perlu dilakukan adalah analisis daya saing. Koperasi perlu mengetahui secara pasti tingkat daya saing produknya dibandingkan dengan produk serupa dari kompetitor. Daya saing produk pembiayaan diantaranya meliputi kemudahan yang diberikan, jangka waktu, fasilitas dan harga untuk produk yang sama.

Setelah dilakukan analisis strategi pemasaran, maka tahap kedua adalah melakukan pengenalan target pemasaran. Tujuan dari tahapan ini adalah untuk mengidentifikasi pasar dari produk yang dihasilkan, misalnya apakah akan dipasarkan hanya kepada anggota koperasi atau masyarakat umum, atau apakah akan ditawarkan kepada calon debitur atau melalui pemasaran jaringan (network marketing). Setelah dilakukan proses identifikasi, maka dapat dilakukan segmentasi pasar sesuai hasil dari proses identifikasi tadi. Setelah proses segmentasi dilakukan maka koperasi dapat menentukan secara rinci daftar calon debitur dan wilayah yang akan menjadi target pemasaran.

Tahapan terakhir dan paling menentukan adalah perencanaan strategi pemasaran, dimana setelah menyelesaikan dua tahapan sebelumnya, koperasi dapat menentukan strategi 
bauran pemasaran dengan cara menentukan kebijakan mengenai produk, penetapan harga dan memilih media sebagai saluran promosi. Tahapan ini harus dilakukan dengan hati-hati berdasarkan analisis dan perencanaan yang telah dilaksanakan pada tahapan sebelumnya. Kebijakan mengenai produk sangat menentukan produk apa yang akan ditawarkan kepada anggota. Apabila koperasi ingin menghasilkan produk yang dapat diterima oleh para pelaku UMK, maka harus mengeluarkan kebijakan yang mendukung kebutuhan para pelaku UMK. Tentunya hal ini akan berdampak pada manajemen dan sumber daya manusia. Kebijakan manajemen akan mempengaruhi proses penetapan harga, karena setiap produk yang ditawarkan memiliki spesifikasi yang berbeda pula.

Begitu pula dalam hal pemilihan media yang akan digunakan sebagai saluran promosi harus direncanakan dengan matang. Dengan beragamnya pilihan media promosi saat ini, baik cetak, elektronik maupun daring (online), harus ditentukan jenis media yang paling cepat, mudah dan murah dalam menjangkau calon pembeli produk koperasi. Apabila koperasi memutuskan untuk menawarkan langsung kepada masyarakat, tentunya perlu dipikirkan suatu strategi merek, yang membuat produk koperasi tersebut mudah diingat dan dikenali. Selain itu keberadaan media sosial seperti Facebook, Twitter, Instagram dan media pengiriman pesan (messaging), seperti Whatsapp, LINE dan BBM perlu dipertimbangkan pula sebagai saluran promosi dalam bauran pemasaran.

\section{Kesimpulan}

Dari pembahasan hasil penelitian dan pembahasan yang telah dilakukan dalam penelitian ini, dapat diambil beberapa kesimpulan sebagai berikut:

Pertama,. Keberadaan Koperasi Baitul Mal wal Tamwil (KBMT) Bina Insan Mandiri di Kabupaten Bogor merupakan indikasi yang positif bagi pengembangan lembaga ekonomi rakyat dalam upaya penguatan lembaga ekonomi sosial masyarakat. Dari hasil penelitian ditemukan beberapa faktor yang menyebabkan tertinggalnya koperasi dibandingkan badan usaha lainnya jika dilihat dari aspek komunikasi pemasarannya. Diantaranya adalah biaya operasional yang relatif tinggi sedangkan bagi hasil rendah, jenis layanan masih terbatas, produk kurang dikenal pasar, rendahnya kompetensi pengurus koperasi, belum menerapkan teknik pemasaran yang efektif, dan wilayah pemasarannya masih bersifat lokal.

Kedua, Meskipun masih banyak kelemahan yang ditemukan dari sistem pemasaran Koperasi Baitul Mal wal Tamwil (KBMT) Bina Insan Mandiri di Kabupaten Bogor, namun dengan potensi pengembangan usaha yang sangat besar, dan adanya pasar yang masih sangat 
terbuka lebar untuk produk pembiayaan Usaha Mikro dan Kecil (UMK) merupakan peluang yang baik bagi KBMT Bina Insan Mandiri di Kabupaten Bogor.

Ketiga, Koperasi Baitul Mal wal Tamwil (KBMT) Bina Insan Mandiri di Kabupaten Bogor belum menggunakan prinsip-prinsip komunikasi pemasaran terintegrasi dalam memasarkan produknya. Sistem pemasaran yang digunakan masih berdasarkan prinsip pemasaran tatap muka tanpa menggunakan media tertentu.

Keempat, Model komunikasi pemasaran terintegrasi yang didasarkan pada berbagai prinsip-prinsip komunikasi pemasaran modern dan meliputi berbagai aspek-aspek pemasaran dapat dipertimbangkan untuk diimplementasikan oleh Koperasi Baitul Mal wal Tamwil (KBMT) Bina Insan Mandiri di Kabupaten Bogor.

\section{Rekomendasi}

Model komunikasi pemasaran organisasi ekonomi sosial kerakyatan seperti KBMT Bina Insan Mandiri yang didirikan untuk memberikan sebesar-besarnya manfaat bagi seluruh anggotanya sangat sesuai dengan falsafah dasar negara Pancasila khususnya sila kedua dan kelima, melalui pembiayaan dengan sistem bagi hasil dan adanya pembagian keuntungan secara merata melalui pembagian Sisa Hasil Usaha kepada seluruh anggota koperasi setiap tahun usaha.

Upaya yang dilakukan KBMT Bina Insan Mandiri di Kabupaten Bogor dalam upaya memenuhi kebutuhan pembiayaan pelaku Usaha Mikro dan Kecil (UMK) harus terus ditingkatkan dengan melakukan diseminasi informasi kepada seluruh kalangan dan kelompok masyarakat, sehingga masyarakat semakin mengenal dan menghayati prinsip-prinsip keadilan sosial yang diterapkan melalui lembaga sosial ekonomi masyarakat seperti koperasi.

Penelitian ini merekomendasikan model komunikasi pemasaran dengan menggunakan prinsip-prinsip komunikasi pemasaran yang terintegrasi dan dirasa cocok untuk diimplementasikan oleh lembaga koperasi. 


\section{DAFTAR PUSTAKA}

Badan Pusat Statistik Provinsi Jawa Barat. 2015. Jawa Barat Dalam Angka. Bandung: BPS Provinsi Jawa Barat.

Dahlan, Abdul Aziz. 2001. Ensiklopedi Hukum Islam. Jakarta: Iktikar Baru.

Denzin, Norman K. dan Guba, Egon. 2001. Teori dan Paradigma Penelitian Sosial; Pemikiran dan Penerapannya, Penyunting: Agus Salim. Yogyakarta: PT Tiara Wacana.

Dinas KUKM Kabupaten Bogor. 2015. Profil Koperasi dan UKM Kabupaten Bogor, 2015. Bogor: Dinas KUKM.

Kotler, Philip. 2008. Manajemen Pemasaran I. Jakarta: Erlangga.

Limbong, W.H. 2007. Pengantar Tataniaga Pertanian. Bogor: Institut Pertanian Bogor.

Miles, Matthew B. dan Huberman, A. Michael. 2012. Analisis Data Kualitatif. Jakarta. Universitas Indonesia Press.

Moleong, Lexy J. 2007. Metode Penelitian Kualitatif. Bandung: Penerbit Rosda.

Morissan, 2010. Periklanan, Komunikasi Pemasaran Terpadu, Jakarta : Kencana.

Mulyana, Deddy. 2007. Ilmu Komunikasi Suatu Pengantar, Bandung: Remaja Rosdakarya.

Pemerintah Daerah Provinsi Jawa Barat. 2015. Profil Kabupaten BogorTahun 2014.

Percy, Larry. 2008. Strategic Integrated Marketing Communication. Oxford, UK: Elsevier.

Pinbuk. 2015 Pedoman Cara Pembentukan BMT Balai Usaha Mandiri Terpadu. Jakarta: Pinbuk.

Pinbuk. 2015. Profil Koperasi Baitul Mal wal Tamwil (KBMT) di Indonesia. Jakarta: Pinbuk.

Ridwan, Muhammad. 2003. Manajemen Baitul Mal wa Tamwil (BMT). Yogyakarta: UII Press. 